UDC 502/504:[574.2:613.16](477)(043)

DOI https://doi.org/10.32846/2306-9716/2020.eco.4-31.22

\title{
FUNCTIONAL AND ECOLOGICAL EXPERTISE IN NEMYRIV DISTRICT IN VINNYTSIA REGION
}

\author{
Yermishev O.V. ${ }^{1}$, Mudrak O.V. ${ }^{2}$ \\ 'Vasyl' Stus Donetsk National University, \\ Yunosti Avenue 16, 21030, Vinnytsia \\ o.yermishev@donnu.edu.ua \\ ${ }^{2}$ MHEI "Vinnytsia Academy of Continuing Education" \\ Hrushevskoho Street, 13, 21000, Vinnytsia \\ ov_mudrak@ukr.net
}

The growing anthropogenic impact on the environment, its pollution with various industrial wastes along with excessive use of natural resources leads to a gradual degradation of the natural environment under the influence of negative anthropogenic factors which is one of the main reasons for the increase of ecologically dependent diseases and constant environmental as well as medical monitoring for operational control of the environmental situation.

781 children of different sexes living in the examined villages Vorobiivka, Hrabovets, Ziankivtsi, Kudlai, Nykyforivtsi, Skrytske, Bratslav, Hrynenky and Novoselivka of Nemyriv district in Vinnytsia region were examined with the help of functional-vegetative electropuncture diagnostics by the method of V.G. Makats. Moreover, the coefficient of the autonomic nervous system (vegetative) was also determined as a result of the ratio of the indicators sum of the sympathetic and parasympathetic autonomic nervous systems.

The children were divided into 3 groups according to the coefficient: those with parasympathetic activity, vegetative-functional balance and sympathetic activity. The number of examined children in the group shown in $\%$ indicates the ecological condition of compact settlement and is the basis of functional and ecological expertise (FEE).

In addition, it forms criteria for the zones of the ecological control. As a result of the research, it has been found for the first time that a decrease in the number of examined children in the vegetative-functional balance zone and an increase in parasympathetic activity are the main characteristics that reflect the negative impact of environmental factors (in this case anthropogenic radiation pollution).

The results of FEE of the children living in the villages Vorobiivka, Hrabovets, Ziankivtsi, Kudlai, Nykyforivtsi, Skrytske, Bratslav, Hrynenky and Novoselivka of Nemyriv district in Vinnytsia region coincide with the results of the state radioecological monitoring of these villages. Accordingly, this testifies to the efficiency and accuracy of the FEE. FEE can be used to assess the impact of any environmental factor on the human body or group of people.

Bioindication methods, which include FEE, can qualitatively and quantitatively assess the biological effects of environmental factors in ecosystems. The use of the human body as a test object is considered to be an advantage of FEE usage which guarantees greater information. Moreover, it not only allows for an integrated assessment of environmental factors and but also to identify the rate of the change occurring in areas of compact settlements. Consequently, FEE will help to regulate the allowable loads on ecosystems that differ in their resistance to the damaging factor and will also allow to make appropriate correlations regarding the possible impact of environmental factors on human health. Key words: ecological monitoring, bioindication, functional health, coefficient of the autonomic nervous system (vegetative), adaptive potential.

Функціонально-екологічна експертиза Немирівського району Вінницької області. Срмішев О.В., Мудрак О.В.

Зростаючий антропогенний вплив на довкілля, його забруднення різними відходами виробництва поряд із надмірним використанням природних ресурсів призводить до поступової деградації природного середовища під впливом негативних антропогенних чинників, що є однією з основних причин збільшення еколого-залежних захворювань і потребує обов'язкового та постійного проведення еколого-медичного моніторингу для оперативного контролю екологічної ситуації.

За допомогою функціонально-вегетативної електропунктурної діагностики за методом В.Г. Макаца було обстежено 781 дитину різних статевовікових груп, які проживають у населених пунктах Воробіївка, Грабовець, Зяньківці, Кудлаї, Никифорівці, Скрицьке, Брацлав, Гриненки та Новоселівка Немирівського району Вінницької області (належать до зони посиленого радіоекологічного контролю) і був визначений коефіцієнт автономної нервової системи (вегетативний), який $є$ результатом співвідношення суми показників симпатичної і парасимпатичної автономної нервової системи.

За коефіцієнтом дітей розподіляли по 3 групах: із парасимпатичною активністю, вегетативно-функціональною рівновагою та симпатичною активністю, де кількість обстежених дітей у групі в \% свідчить про екологічний стан територій компактного проживання, є основою функціонально-екологічної експертизи (далі - ФЕЕ) і формує критерії зон екологічного контролю.

У результаті досліджень вперше було з'ясовано, що основною характеристикою, яка відображає негативний вплив екологічних факторів (у цьому випадку антропогенне радіаційне забруднення), є зменшення кількості обстежених дітей у зоні вегетативно-функціональної рівноваги і збільшення їх у зоні парасимпатичної активності від розробленої нами норми.

Результати проведення ФЕЕ дітей, які проживають у населених пунктах Воробіївка, Грабовець, Зяньківці, Кудлаї, Никифорівці, Скрицьке, Брацлав, Гриненки та Новоселівка Немирівського району Вінницької області, збігаються 3 результатами державного радіоекологічного моніторингу цих населених пунктів, що свідчить про ефективність і точність ФЕЕ. ФЕЕ можна використовувати для оцінки впливу будь-якого екологічного фактору на організм людини чи на групу людей. Методами біоіндикації, до яких належить ФЕЕ, можна якісно і кількісно оцінити біологічні ефекти дії екологічних факторів в екосистемах. 
Перевагою використання ФЕЕ є використання в якості тест-об'єкта організму людини, що гарантує більшу інформативність і дає можливість здійснювати інтегральну оцінку дії екологічних факторів і виявляти швидкість змін, що відбуваються на територіях компактного проживання населення. ФЕЕ допоможе унормувати допустимі навантаження на екосистеми, що відрізняються за своєю стійкістю до вражаючого чинника, та дозволить проводити відповідні кореляції стосовно можливого впливу екологічних факторів на здоров'я людини. Ключові слова: екологічний моніторинг, біоіндикація, функціональне здоров’я, коефіцієнт автономної нервової системи (вегетативний), адаптаційний потенціал.

Problem formulation. Currently, the environment is under significant anthropogenic pressure which directly affects the health of the population. Every year the level of ecologically dependent diseases of the population in our country increases which requires mandatory and constant ecological and medical monitoring. Environmental and medical monitoring should be considered as a tool for operational control of the environmental situation and its impact on public health, which allows timely and reasonable decisions to choose priority measures and long-term management plans for government agencies.

The ratio of the activity of the two parts of the autonomic nervous system - sympathetic and parasympathetic in the human body under the action of abiotic and anthropogenic (radiation pollution) factors is the object of the study. The functional and vegetative health of children is the subject of the study. Integral bioindicators of individual health are the levels of autonomic disorders and characterize the ecological situation in the region of compact living.

The purpose of the study is to verify the radiation dependence of functional and vegetative health as well as dosimetric certification of settlements of Nemyriv district in Vinnytsia region with the help of the developed by us functional and ecological expertise. The task of the study was to study the characteristics of the impact of anthropogenic environmental factors on the functioning of the autonomic nervous system in children as a result of the accident at the Chernobyl nuclear power station.

The research relevance. Nowadays, one of the greatest dangers for the population of Ukraine is played by radioactive contamination the level of which is the only state-controlled at the legislative level environmental and anthropogenic factor of negative impact on the human body. The concept of functional and ecological examination (FEE) of the regions of the radiation control of Ukraine developed by us confirms the expediency of the state attention to the problem of "Ecological certification of children" (prof. V.G. Makats) and fundamentally complements the accepted forms of dosimetric and thyroid dosimetric control.

The connection of the author's work with important scientific and practical tasks. The research work is fragment of the state program "Two-stage system of rehabilitation of autonomic disorders of children living in the radiation control zone of Ukraine" (performed on behalf of the Cabinet of Ministers of Ukraine dated 01.06.1999 № 12010/87) and a planned research work "Scientific and methodological principles of adaptive health of radioactively contaminated and relatively clean areas of environmental control in the context of sustainable development strategy of Ukraine" (state registration number 0117U103571) carried out at the Department of Biophysics and Physiology of Vasyl' Stus Donetsk National University.

The fact that for the first time the indicator of functional and vegetative health of the organism is offered as a criterion of ecological well-being of the region has become the novelty of the study results. The studies have shown for the first time that a decrease of the number of examined people in the area of functional balance and an increase of the one in the area of parasympathetic activity is the main characteristic that reflects the negative impact of external and internal factors.

It is revealed that the results of FEE coincide and fundamentally complement the accepted forms of radioecological, dosimetric and thyroid dosimetric state monitoring. Studies have shown for the first time that the main characteristic that reflects the negative impact of external and internal factors is a decrease in the number of examined people in the area of functional balance and an increase in the area of parasympathetic activity. It has been revealed that the results of FEE coincide and fundamentally complement the accepted forms of radioecological, dosimetric and thyroid dosimetric state monitoring.

The methodological or general scientific significance lies in the fact that the results of the study can be used for ecological monitoring of areas with compact population living. The analysis of functional and vegetative health of the population related to the medical and ecological effects of the environment is important for early detection of pre-nosological conditions and prevention of pathology which are priority areas of human ecology in the face of abrupt changes in the habitat.

The analysis of recent research studies and publications. The ecology of the environment and human health directly depends on the combined impact of environmental factors, their levels and action duration on ecosystems and the human body. Given the constant increase in pollutants, including ecotoxicants, as the most dangerous to the environment and human health, it is extremely important to conduct ecobiological monitoring which allows to determine the degree of environmental pollution $[2 ; 10]$.

In turn, the obtained data make it possible to assess the impact of pollutants on ecosystems and can be used to prevent or reduce their entry into the environment $[5 ; 10]$. Currently, physical and chemical methods of monitoring the ecological state, which allows to ana- 
lyze it in comparison with the normative concentrations established for biota are the main methods of assessing the state of the environment.

Analytical methods are the simplest and fastest methods for identifying areas of environmental distress, though, they do not allow to directly determine the manifestation of the effects of pollutants on the body and its vital functions. In addition, the use of physicochemical methods does not allow to detect the combined effect of several environmental factors (anthropogenic, abiotic and biotic) on the body and to establish possible secondary, consequential effects, i.e to obtain sufficient data necessary to establish regulatory concentrations of pollutants (ecotoxicants).

This, as well as many other information, can be obtained by using bioindication methods which are based on the reactions of living organisms and their communities to the action of ecotoxicants $[6 ; 10]$. It is based on the observation of the composition, number as well as morphological, physiological, biochemical changes in the body of bioindicators (organisms that serve as test objects) under the influence of environmental factors. The obtained results are used to identify dangerous areas for human life.

Today, there is a need to develop and implement the methods for detecting environmental damage directly using the human body in the practice of environmental monitoring. That will provide more informative and reliable assessment of the impact of environmental factors. The method of functional-ecological examination (FEE) that has been offered by us allows to directly use a person as a test object. In order to assess the reliability of the FEE method we compared its results with the results of the state radioecological monitoring, which the only state-controlled environmental and anthropogenic factor of negative impact on the human body.

The main subject of the research of the FEE method is the complex state of the autonomic nervous system (ANS) of the child's body and the analysis of the processes that affect it. The autonomic nervous system is known to regulate all internal processes in the body and perform an adaptive and trophic function - the regulation of metabolism, adapting them to changing environmental conditions $[4 ; 9 ; 11]$.

There are many methods of studying individual indicators of the ANS but most of them unreliable due to low recurrence (repeated results do not coincide with the previous ones) and limited to the assessment of the ANS, which controls the physiological activity of certain physiological systems. Functional-vegetative diagnostics (FVD) of the vegetative health of the population by the method of V. Makats is deprived of these shortcomings that allows to reveal indicators of vegetative levels variance which act as integral bioindicators of homeostatic reactions of a human body and its dependence on changing environmental conditions $[7 ; 8 ; 11]$.

On this basis, an integrated characteristic of the ecological state is formed and the levels (zones) of its eco- logical pressure are determined. Identification and study of causal relationships between the influence of environmental factors and changes in human adaptive potential is one of the urgent tasks of ecological and biological monitoring $[2 ; 6 ; 7 ; 11]$, the main purpose of which is to identify the relationship between the environment and individual or population health. Functional health (an adaptation potential) of the population more objectively reflects the ecological changes of the territory, as it characterizes the ability of the organism to adapt to changing conditions of the external and internal environment $[8 ; 11]$.

Materials and methods. The correlations between changes in electrical conductivity of 24 representative FAZ (characterizing the state of the meridian as a unity) and the state of classical acupuncture meridians "determining" the functional state of their respective internal organs and systems of the organism are used for the diagnosis. 781 children of different sexes living in the examined villages Vorobiivka, Hrabovets, Ziankivtsi, Kudlai, Nykyforivtsi, Skrytske, Bratslav, Hrynenky and Novoselivka of Nemyriv district in Vinnytsia region were examined with the help of functional-vegetative electropuncture diagnostics (FVD) by the method of V.G. Makats.

FVD was conducted in the morning (10:00-12:00). The bioelectric activity of 12 symmetric pairs of functionally active skin zones (24 FAZ), 12 on the hands and 12 on the feet, which reflect the functional activity of the sympathetic and parasympathetic nervous systems, was studied $[5 ; 8]$. The FVD according to the method of V. Makats and devices for its implementation were officially approved by the Ministry of Health of Ukraine "New Medical Equipment and New Methods of Diagnosis" (№ 5 from 25.12.91; № 1.08-01 from 11.01.94) and the Scientific Council of the Ministry of Health of Ukraine (№ 1.08-01 of 11/01/94).

A VITA $01 \mathrm{M}$ device is used for FVD, the voltage in the closed circuit of which does not exceed the levels of membrane potentials $(1-5 \mu \mathrm{A} ; 0.03-0.6 \mathrm{~V})$. The device does not require external energy sources for its operation. It has 2 diagnostic electrodes, a base electrode acceptor of electrons (AE) -a convex plate of a special alloy, pre-coated with an oxide film $(5 \times 7 \mathrm{~cm})$ and 2 paired diagnostic electrodes (DE - electron donors) in the form of a silvered pair, which are located in ebonite cups with a diameter of $1 \mathrm{~cm}$ and wrapped with foam gaskets.

The base electrode (AE) is fixed by a special belt through a moist pad (moistened with saline solution) in the umbilical region (central mesogastric area (0-zone) with medium density tension to create stable examination conditions. Diagnostic electrodes (DE) are also moistened with saline solution. The procedure is performed in the orthostatic position of a person. In the process of testing electrodes, DE are placed at right angles with a slight pressure (at the touch level), simultaneously are contacted with each pair of symmetric FAZ (left-right at each extremity) for 1-4 seconds to obtain 
stable performance in micro amperes. Electrodes are remoistened with saline solution after every 3 contacts with the FAZ.

Obtained in $\mathrm{mA}$ data of FVD are transformed into relative values. The obtained data are compared with the norm and it is concluded about the degree of deviation from it and the level of functional health impairment $[7,8,11]$. Mathematical and statistical processing of the results of the observations was carried out using the method of nonparametric statistics proposed by E.A. Derevyanko to determine the magnitude of the shift of the function under the study [1].

Presentation of the main material. In Vinnytsia region, 89 settlements in Vinnytsia region are in the zone of enhanced radioecological control, including 19 ones in Nemyriv district. Nemyriv district is located in the central part of Vinnytsia region, which belongs to the forest-steppe physical geographical zone of Vinnytsia region including Nemyriv and 94 settlements. The area of the district is $1293 \mathrm{~km}^{2}$, where 48,347 people live (January 1, 2018).

The functional health (adaptation potential) of certain age groups of children is in the focus of FEE, which becomes a "bioindicator" of individual health and characterizes the ecological dynamics in the region of compact living. It has been established that the levels of functional health are specific markers of the adaptation state of the organism to changing conditions of external and internal environments. Moreover, they reflect the general functional-vegetative homeostasis of the human body. FEE criteria should be correlated with the levels of radionuclide (environmental) contamination in the controlled monitoring regions of Nemyriv district in Vinnytsia region.

As a result of the FVD by Makats, the indicators of the activity of sympathetic and parasympathetic nervous systems in mkA which were transformed into relative values and defined as a direction of vegetative balance have been received. The vegetative coefficient $\mathrm{kV}$ is the numerical result of this ratio, according to which seven levels of vegetative dispersion (scattering) of functional health are distinguished today: PAs is a zone of significant parasympathetic activity ( $\mathrm{kV}$ up to 0.75 ); PAe - a zone of expressed parasympathetic activity ( $\mathrm{kV} \mathrm{0.76-0.86);} \mathrm{VE} \mathrm{-} \mathrm{zone} \mathrm{of} \mathrm{functional} \mathrm{compensation}$ of parasympathetic activity (kV 0.87-0.94); PVB - zone of functional vegetative equilibrium ( $\mathrm{kV}$ 0.95-1.05); $\mathrm{FcS}$ - zone of functional compensation of sympathetic activity (kV 1.06-1.13); SAe is a zone of expressed sympathetic activity ( $\mathrm{kV}$ 1.14-1.26) and SAs is a zone of significant sympathetic activity $(\mathrm{k}-\mathrm{V}>1.26)$.

Though, it is more convenient to use vegetative dispersion (scattering) according to critical zones for functional-ecological assessment of the environmental factors influence, i.e the ratio of parasympathetic activity - PA (PAs + PAe $)$ - vegetative-functional equilibrium - VE $(\mathrm{FcP}+\mathrm{VE}+\mathrm{FcS})-$ sympathetic activity $(\mathrm{SAs}+\mathrm{SAe})$. The obtained data on the state of functional health of the population of a certain area as well as average information on disorders of the autonomic nervous system can be used to analyze the impact of integrated environmental pressure on the human body, possible environmental problems and the degree of environmental impact $[8 ; 11]$.

In the suggested method of functional and ecological examination (FEE), the number of people (\%) whose indicators of functional health are in a state of functional depression (PA - predominance of parasympathetic activity), vegetative equilibrium (VE) and the number of cases of predominance of functional excitation (SA - predominance of sympathetic activity) is the basis of the systematic analysis.

According to the criteria prepared by us, the functional health (adaptive potential) of a person is in the zone of functional safety, when $70 \%$ of people are in the zone of vegetative-functional equilibrium (VE) and $15 \%$ are in the zones of parasympathetic and sympathetic activity. The decrease in the number of examined people in the area of functional balance and the increase of them in the area of parasympathetic activity is the main characteristic that reflects the negative impact of external and internal factors (Table 1) [8; 11].

Among the pollutants, the greatest attention is paid to radioactive contamination of the environment which is the only currently controlled factor. In 1989-1992, the density of radioactive contamination $137 \mathrm{Cs}$ was mistakably accepted as a danger criterion (this is an area with a density of soil contamination above the pre-emergency level of Cesium isotopes of $15.0 \mathrm{Ki} / \mathrm{km}^{2}$ and it was defined above as unconditional (compulsory) resettlement of the population). This led to some exceeding of the contamination standards of milk and meat,

Indicators of functional and ecological expertise

Table 1

\begin{tabular}{|l|c|c|c|}
\hline \multicolumn{1}{|c|}{ The region of ecological control } & \multicolumn{2}{c|}{ Vegetative state in\% } \\
\cline { 2 - 4 } & PA zona & VE zona & SA zona \\
\hline Zone of relative functional safety - RFS & 15 & 70 & 15 \\
\hline Zone of high functional attention - HFA & 25 & 50 & 25 \\
\hline Functional voltage development zone - FVD & 30 & 50 & 20 \\
\hline Zone of functional disaster development -FDD & 45 & 40 & 15 \\
\hline Functional disaster zone - FDZ & 65 & 25 & 10 \\
\hline Functional protection voltage zone - FPV & 10 & 25 & 65 \\
\hline
\end{tabular}


which had a corresponding impact on children's health. Precipitation of radioactive clouds increased in rainy weather. Therefore, contamination of $137 \mathrm{Cs}$, $90 \mathrm{Sr}$ (and other radionuclides) has a clear spotting character and may be different. This situation applies even to "conditionally clean" areas [3].

It is known that the surveyed villages such as Vorobiyivka, Grabovets, Zyankivtsi, Kudlay, Nykyforivtsi, Skrytske, the Bratslav town, Hrynenky and Novoselivka belong to the zone of enhanced radioecological control (IV zone) (Table 2) [3]. For 3 years (from 1994 to 1996), we conducted a survey of children to identify changes in functional health (adaptive potential) associated with the cumulative biological effect of radionuclides and compare the results with the results of state radioecological monitoring.

In the study of the functional health of children in the villages Vorobiyivka and Grabovets in 1995 it was found that the variance of autonomic levels (levels of autonomic balance) in the female and male groups had a dynamic identity, though in the male group there is a more pronounced deterioration in the functional health of children, indicating gender features of functional health (adaptive potential) children.

Moreover, observations in the female and male groups indicate the relationship of Vorobiyivka and the village of Grabovets to the zone of "the development of functional catastrophe" (DFC) and as a whole corresponds to the state radioecological monitoring (4th zone of radioecological control) (fig. 1).

A study of the functional health of children in the villages of Zyankivtsi, Kudlay, Nikiforivtsi and Skrytske in 1994 found that the variance of vegetative levels (levels of autonomic balance) in the female and male groups had a dynamic identity, but there is a more pronounced state of health of children in the female group (Fig. 2).

The observations made by us in 1994 revealed gender features of children's functional health (adaptive capacity). Observations in the female and male groups indicate the ratio of the villages of Zyankivtsi, Kudlai, Nikiforivtsi and Skrytske to the zone of "the development of functional tension" (DFT) in the female group

Table 2

Radiological indicators of the surveyed settlements (2006) and the results of functional and ecological examination

\begin{tabular}{|c|c|c|c|c|c|c|c|c|}
\hline \multirow{2}{*}{ The settlement } & \multirow{2}{*}{ Year } & \multirow{2}{*}{ ChNPS } & \multicolumn{2}{|c|}{$\mathrm{Cs}^{137} \mathrm{kB} / \mathrm{m}^{2}$} & \multicolumn{3}{|c|}{ M3v/year for year } & \multirow{2}{*}{ FEE } \\
\hline & & & soil & milk & 2006 & 70 years & HRC & \\
\hline Vorobiyivka & 1995 & 4-та & 60,8 & 60,8 & 0,18 & 8,8 & 60,8 & FDD \\
\hline Grabovets & 1995 & 4-та & 50,4 & 50,4 & 0,15 & 7,3 & 50,4 & FDD \\
\hline \multirow{2}{*}{ Zyankivtsi } & \multirow{2}{*}{1994} & \multirow{2}{*}{ 4-та } & \multirow{2}{*}{29,5} & \multirow{2}{*}{29,5} & \multirow{2}{*}{0,10} & \multirow{2}{*}{4,3} & \multirow{2}{*}{29,5} & FVD \\
\hline & & & & & & & & RFS \\
\hline Kudlay & 1994 & 4-та & 34,0 & 34,0 & 0,11 & 4,5 & 34,0 & \multirow{3}{*}{ FVD / RFS } \\
\hline Nikiforivtsi & 1994 & 4-та & 44,2 & 44,2 & 0,14 & 6,3 & 44,2 & \\
\hline Skrytske & 1994 & 4-та & 0,14 & 5,8 & 2,2 & 0,02 & 0,14 & \\
\hline Bratslav & \multirow{3}{*}{1994} & 4-та & 13,7 & 13,7 & 0,07 & 1,5 & 13,7 & \multirow{3}{*}{ RFS } \\
\hline Grinenki & & 4-та & 25,2 & 25,2 & 0,08 & 4,2 & 25,2 & \\
\hline Novoselivka & & 4-та & 18,5 & 18,5 & 0,07 & 2,9 & 18,5 & \\
\hline Bratslav & \multirow{3}{*}{1995} & 4-та & 13,7 & 13,7 & 0,07 & 1,5 & 13,7 & \multirow{3}{*}{ HFA / FDZ } \\
\hline Grinenki & & 4-та & 25,2 & 25,2 & 0,08 & 4,2 & 25,2 & \\
\hline Novoselivka & & 4-та & 18,5 & 18,5 & 0,07 & 2,9 & 18,5 & \\
\hline Bratslav & \multirow{3}{*}{1996} & 4-та & 4-та & 13,7 & 13,7 & 0,07 & 1,5 & \multirow{3}{*}{ FDZ } \\
\hline \begin{tabular}{|l|} 
Grinenki \\
\end{tabular} & & 4-та & 4-та & 25,2 & 25,2 & 0,08 & 4,2 & \\
\hline Novoselivka & & 4-та & 4 & 5 & - & 0,07 & 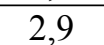 & \\
\hline
\end{tabular}

Note: HRC - human radiation counter.

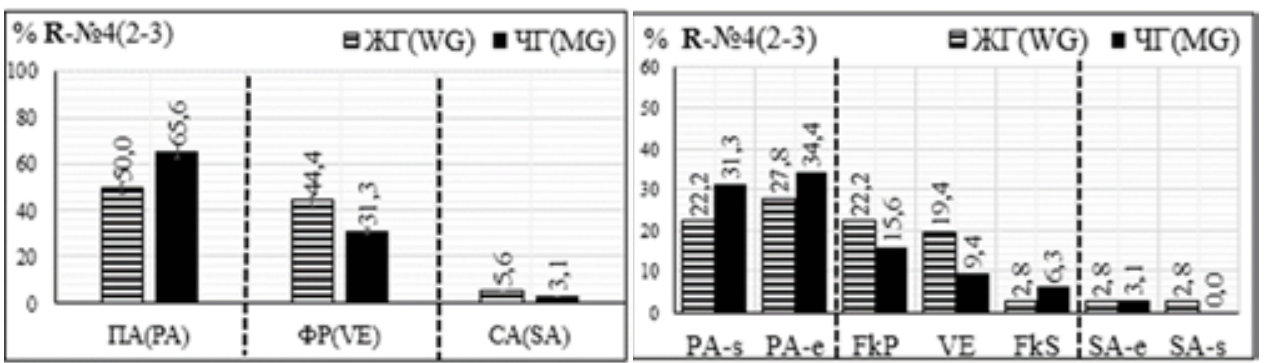

Fig. 1. Critical vegetative zones and levels of vegetative balance of children in the villages of Vorobiyivka, Grabovets and Golynchyntsi (1995) 
and to the zone of "functional safety" (FS) in the male group (Fig. 1). The results of FEE in the villages of Zyankivtsi, Kudlay, Nykyforivtsi and Skrytske do not coincide with the official dosimetric certification of these settlements.

The FEE results obtained during the survey of the children population of different villages of Nemyriv district, which belong to the 4th zone of the Chernobyl NPS, have a specific character and do not coincide with each other. This may indicate, first of all, the "spotty" nature of radioactive contamination of the surveyed areas. Secondly, the impact on the body of additional exo- and endoecological environmental factors which leads to changes in the functional health of children.

The study of functional health of children in Bratslav, Hrynenky and Novoselivka in 1994-1996 found that

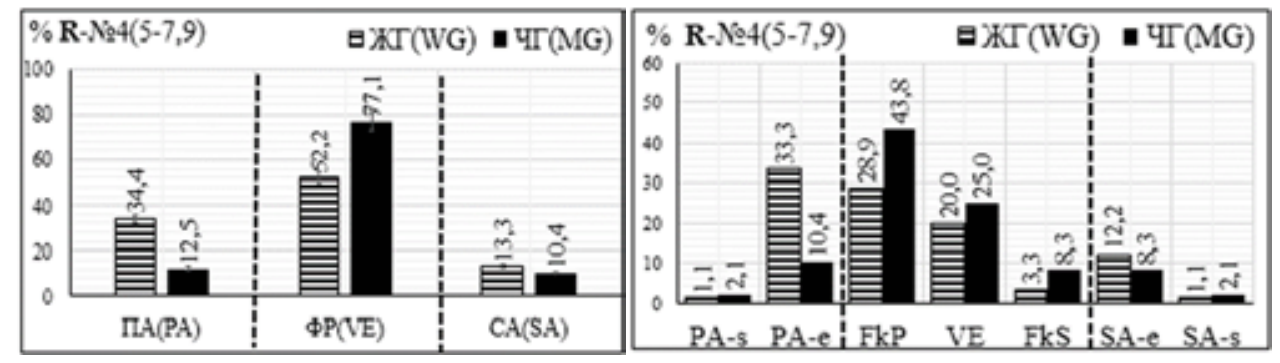

Fig. 2. Critical vegetative zones and levels of vegetative balance of children in the villages of Zyankivtsi, Kudlay, Nikiforivtsi and Skrytske (1994)

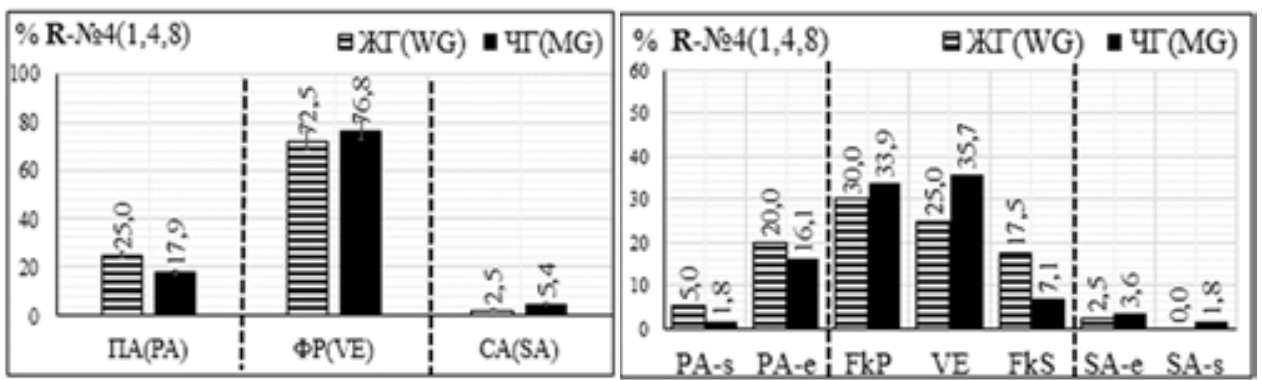

Fig. 3. Critical vegetative zones and levels of vegetative balance of children in Bratslav, Hrynenko and Novoselivka (1994)

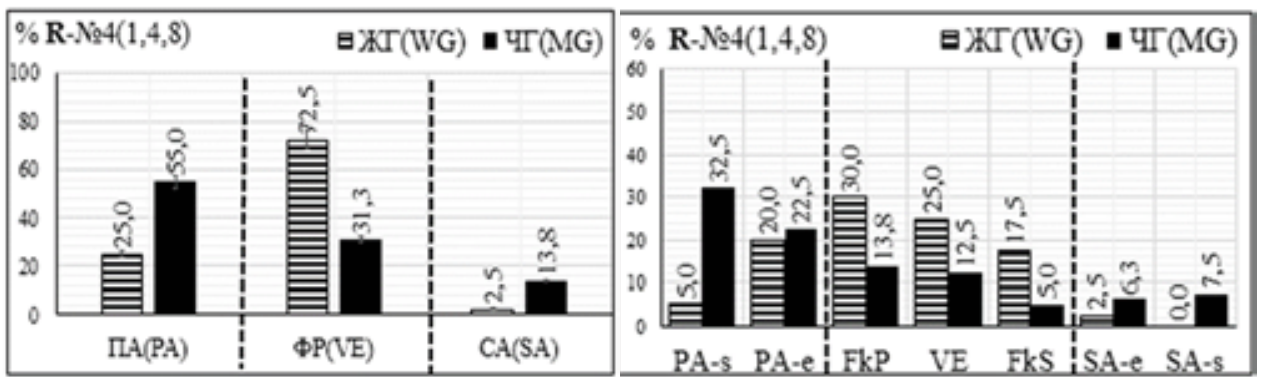

Fig. 4. Critical vegetative zones and levels of vegetative balance of children living in the villages of Bratslav, Hrynenko and Novoselivka (1995)

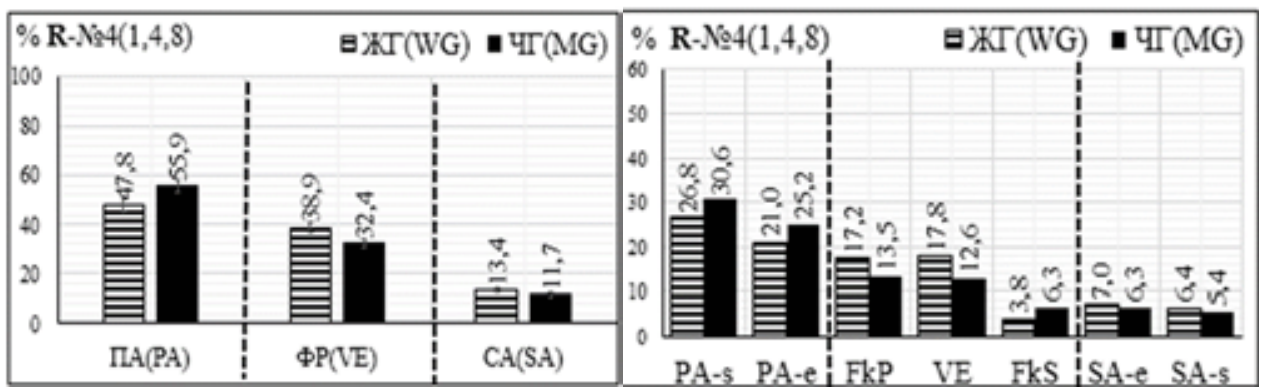

Fig. 5. Critical vegetative zones and levels of vegetative balance of children living in the Bratslav, Hrynenko and Novoselivka (1996) 
the variance of vegetative levels (levels of vegetative balance) in the female and male groups had a dynamic identity. Though, while there was a more pronounced deterioration of children's functional health in the female group in 1994 and in 1995-1996, a sharp deterioration in functional health was detected in the male observation group, which in turn indicates the presence of gender features of functional health (adaptive potential).

Observations in women's and men's groups in 1994 indicate the relationship of the town Bratslav and the villages ofHrynenky and Novoselivka to the "functional safety" zone (FS) and do not coincide with the official dosimetric certification of these villages (Fig. 3).

Our observations conducted in 1995 in the female and male groups indicate the relationship of the villages Bratslav, Hrynenky and Novoselivka to the zone of "increased functional attention" (IFA) in the female observation group and to the zone of "functional-ecological catastrophe" (FEC) in the male observation group and coincide with the official dosimetric certification of these settlements (Fig. 4).

Observations in the female and male groups conducted in 1996 indicate the relationship of the town Bratslav and the villages Hrynenky and Novoselivka to the zone of "functional-ecological catastrophe" (FEC) in both groups of observations and coincide with the official dosimetric certification of these settlements (Fig. 5).

Observations in 1994-1996 in Bratslav, Hrynenko and Novoselivka revealed a gradual increase in the number of examined children in the area of parasympathetic activity, which may indicate a decrease in children's adaptive potential, depletion of adaptive reserves as well as deteriorating environmental living conditions of children.

Thus, in the female observation group, the number of children in the area of parasympathetic activity increased by $22.8 \%$ in 1996 in comparison with 1994-1995. As for the male group it increased by $37.1 \%$ in 1995 and by $38 \%$ in 1996, compared with 1994. At the same time, there was a significant decrease in the examined children in the zone of vegetative-functional balance in 1996 to $38.9 \%$ in the female group and $32.4 \%$ in the male group, which is $70 \%$ much lower due to the norm developed by us.

The accumulation of radionuclides in the body of children leads to the changes in the endoecology of the child's body, violation of the neuro-humoral regulation of physiological functions and confirms the negative pressure of the radiation component on the functional health of children. Bioindication methods, which include FEE, can qualitatively and quantitatively assess the biological effects of environmental factors in ecosystems. The use of the human body as a test object, which guarantees greater information, is the advantage of using FEE. It makes it possible to carry out an integrated assessment of the effects of environmental factors and identify the rate of changes occurring in areas of compact living.

\section{The main conclusions.}

1. Functional and vegetative health of children is ecologically dependent and is a bioindicator as well as the basis of FEE regions of environmental control.

2 . The indicators of functional and vegetative health of children are the most sensitive bioindicators of environmental pollution.

3. The results of FEE of the surveyed villages of Nemyriv district coincide with their official dosimetric certification.

4. The monitoring of vegetative health of children should become the basis of modern functional medical examination of the child population and complement the state dosimetric and thyroid dosimetric certification of residential environments.

\section{References}

1. Григорьев А.И., Григорьев К.И. Роль неблагоприятных факторов окружающей среды в формировании нарушений адаптации у детей и подростков. Медицинская сестра. 2018. № 7. С. 32-38. DOI: https://doi.org/10.29296/25879979-2018-07-07.

2. Срмішев О., Петрук Р., Овчинникова Ю., Костюк В. Функціональне здоров'я дітей як екологічний біоіндикатор України (Вінницька, Львівська, Чернігівська області / за ред. професора В.Г. Макаца. Вінниця: «Наукова ініціатива», 2017. 226 с.

3. Интегральная оценка работоспособности при умственном и физическом труде / под ред. Е.А. Деревянко. М. : Экономика, 1990. $109 \mathrm{c}$.

4. Киричук А.А., Черных Н.А., Баева Ю.И. Активность, дисбаланс и адаптационные реакции функциональных систем организма иностранных студентов Российского университета дружбы народов в условиях мегаполиса. Экология человека. 2019. № 1. C. 20-25. https://doi.org/10.33396/1728-0869-2019-1-20-25.

5. Константинова Е.Д., Маслакова Т.А., Шалаумова Ю.В., Вараксин А.Н., Живодеров А.А. Радиоактивное загрязнение территории и адаптационная реакция организма человека. Экология человека. 2019. № 2. С. 4-11. https://doi.org/10.33396/ 1728-0869-2019-2-4-11.

6. Макац В., Нагайчук В., Макац Є., Єрмішев О. Невідома китайська голкотерапія (проблеми вегетативного патогенезу). Том IV. Вінниця, 2017. 286 с.

7. Макац В.Г., Курик М.В., Петрук В.Г., Нагайчук В.І., Срмішев О.В. Основи функціонально-екологічної експертизи (невідома вегетологія). Том VI. Вінниця, 2018. 128 с.

8. Моніторинг екосистем: цілі та необхідність, роль індикації / В.М. Войціцький, С.В. Мідик, Т.В. Полтавченко, О.В. Березовський, О.Ю. Кеппл, А.О. Велинська. Біоресурси і природокористування. 2019. Т. 11, № 3-4. С. 9-46. https://doi.org/10.31548/ bio2019.03.005

9. Радіологічний стан територій, віднесених до зон радіоактивного забруднення (у розрізі районів) / МНС України у справах захисту населення від наслідків Чорнобильської катастрофи / за загальною редакцією В.І. Холоші. Київ : ТОВ Інтелектуалі системи ГЕО, 2008. 49 c.

10. Jänig W. Integrative Action of the Autonomic Nervous System. Neurobiology of Homeostasis. Cambridge University Press; $2008: 636$.

11. Parashar R., Amir M., Pakhare A., Rathi P. Age Related Changes in Autonomic Functions. Journal of Clinical and Diagnostic Research. 2016; 10 (3): 11-13. https://doi.org/10.7860/JCDR/2016/16889.7497. 